\title{
IMPACT OF POLYPARASITISM ON THE HAEMOGLOBIN VALUES OF PRIMARY SCHOOL CHILDREN IN AKPET CENTRAL BIASE- NIGERIA
}

\section{A. M. AKEH, C. A. EMEKOM, C. I. MBOTO AND J. O. OGBECHE}

(Received 1, July 2008; Revision Accepted 13, January 2009)

\begin{abstract}
The relationship between parasitic infections and development of anemia was investigated among pupils of Presbyterian primary school, and Government primary School Akpet Central in Biase Local Government Area, Cross River State of Nigeria. A total of 420 stool and corresponding blood samples were collected and examined for the presence of parasites and anemia respectively. The stool samples were examined using the direct smear and floatation techniques while haemoglobin was determined using the cynmethaemoglobin method. The result obtained revealed high prevalence of Plasmodium falciparun $(65.0 \%, 273 / 420)$ and intestinal parasites $(78.1 \%, 328 / 420)$ with the associated anemia. Ascaris lumbricoides was the commonest parasite seen (71.88\%, 230/420), followed closely by hook worm $(68.90 \%, 226 / 420)$. Infection with intestinal protozoa was few while no tape worm was seen. There was significant differences $(P<0.05)$ in the haemoglobin levels between the infected and the uninfected pupils; there was however no significant difference $(P<0.05)$ in the infection rate by sex. From the observation of the results, malaria and intestinal parasites are major contributing factors of anemia among school pupils in Akpet Central. The results are further examined while recommendations for the control of these infections in this locality are highlighted.
\end{abstract}

KEYWORDS: Polyparasitism, Haemoglobin, School children, Akpet Central.

\section{INTRODUCTION}

Anemia is the second most common cause of disability in the world (Murray and Lopez, 1996), and is reflected in several of the global Millennium Development Goals. (United Nation, 2007).

The aetiology of anemia is multifactorial in developing countries and includes deficiency of micronutrients, haemoglobinopathies, infections and chronic disease e.g. malaria, schistosomiasis, Helminthes, HIV and tuberculosis (Bate et al, 2007).

The amount of blood loss in hookworm infections is strongly and linearly correlated with worm load and faecal egg count, and even light infections contribute significantly to anemia (Stoltzfus et al. 1996). Trichuris trichiura also causes intestinal blood loss, and school children with heavy .trichiura infections have a higher prevalence of anemia (Randath et al, 1995).

Schistosoma and other parasites cause anemia either directly through blood loss or indirectly through bone marrow suppression, inflammation, hypersplenism, haemolysis, or anorexia (Friedman et al, 2005 and Stephenson et. al, 2000). Anemia is particularly common in individuals infected with soil transmitted helminthes or schistosoma infection with several parasites at once. Polyparasitism is common in tropical countries, particularly in poor communities. There is an inverse relationship between the number of parasites in an infected person and their haemoglobin level. For example low intensity polyparasitic infections in children in the Philippines have been associated with 5 -fold increase in prevalence of anemia (Ezeamana et al,
2005). Moderate/high intensity of infections with three or four soil transmitted helminthes and S.japonicum are associated with 8-fold increase in anemia (Ezeamana et al, 2005).

Various disease disorders manifest in anemia, however, the role of malaria and other parasites commonly encountered in this community and their relationship to anemia is the subject of this investigation.

\section{MATERIALS AND METHODS}

\section{Study Area}

This study was conducted among pupils in Presbyterian primary School and Government Primary school in Akpet Central, Biase Local Government of Cross River State-Nigeria. These are the only primary schools in the area. Pupils from primary $2-6$ were used as those in primary 1 were not easy to organize.

The area is situated at the Central senatorial district of the state about $120 \mathrm{~km}$ from the coastal town of Calabar the state capital. Akpet Central falls in the tropical forest belt of south eastern Nigeria.

The climate is a typical tropical humid climate with distinct rainy and dry seasons. The dry season stretches from November to March while the rainy season is from April to October. Akpet Central was a typical rural community until recently when it was made the capital of Biase Local Government Area.

The population in this community is fast growing judging from its increase from an estimated population of 8 thousand in 1991 to about 15 thousand now. The people are homogenous and speak a common language

\footnotetext{
A. M. Akeh, Department of Biological Science, Cross River University of Technology, Calabar, Nigeria.

C. A. Emekom, General Hospital Arondizuogu, Imo State, Nigeria.

C. I. Mboto, Department of Microbiology, University of Calabar, Nigeria.

J. O. Ogbeche, Department of Biological Science, Cross River University of Technology, Calabar, Nigeria.
} 
which is understood by all indigenes. This community lacks pipe-borne water and is heavily dependent on streams scattered all over the area for their domestic, agricultural and economic water supply. Economic activities in this area include farming, petty trading, cassava processing, rice farming and small scale fishing.

Houses are not properly designed; they are mostly made of mud bricks, some having cracks and crevices all over. Most of them defecate in nearly bushes since most households do not have toilet facilities.

\section{Blood sample collection and Laboratory Analysis}

The capillary method of blood collection was adopted since the amount of blood needed was small. The third finger was used to avoid contact with nerves and this finger has been found to be less painful (WHO 1991).

The finger was swabbed with cotton wool soaked in $70 \%$ ethanol and was adequately pricked with sterile blood lancet to extract capillary blood. The first drop of blood was wiped, while a large drop which flowed subsequently was placed on a clean grease-free glass slide. This was spread in a circle to form a thick film. A drop of blood was placed at one end of the slide and spread using a spreader to form a thin film (Cheesbrough, 1992). An aliquot of $0.02 \mathrm{ml}$ of the blood was withdrawn using haemoglobin $(\mathrm{Hb})$ pipette into $4 \mathrm{mls}$ of Drabkin's solution and mixed. The films were allowed to air dry and the thin blood film fixed with absolute methanaol for 2 minutes. Slides were packed carefully into a slide box and the diluted blood into a small carton and transported to the laboratory for examination and reading.

\section{STOOL SAMPLE COLLECTION}

Stool samples were collected into clean leak proof, wide-mouthed containers with fitting covers.

Macroscopy: Physical appearance of stool was first noted and recorded, after which $1 \mathrm{~g}$ of each stool samples was treated with $7 \mathrm{mls}$ of $10 \% \mathrm{v} / \mathrm{v}$ formal saline fixative. The fixed stool samples were carefully packed into a portable carton and transported to the laboratory for examination.

\section{EXAMINATION OF BLOOD SPECIMEN}

\section{Haemoglobin (Hb)Estimation}

Method used: Cyanmethaemoglobin (Evatt, et al, 1992) An aliquot of $0.02 \mathrm{ml}$ of blood was added to $4 \mathrm{mls}$ of Drabkins solution and allowed to stand for 10 minutes for colour development. The colorimeter was zeroed using undiluted Drabkin's solution. The mixed solution was then placed into the colorimeter for reading at $540 \mathrm{~nm}$ wavelength and result calculated as follows;

$$
\begin{aligned}
& \mathrm{Hb}=\frac{\text { Absorbance of Test }}{\text { Absorbance of standard }} \times \frac{\text { Concentration of standard }}{1} \\
& \mathrm{Hb}=\frac{\text { Absorbance of Test }}{\text { Absorbance of standard }}
\end{aligned}
$$

\section{Thick and Thin blood Films for malaria Parasites}

The air dried thick and thin films were stained using $2 \%$ Giemsa stain solution for 30 minutes. The slides were then washed in phosphate buffer p.H 7.2 and allowed to dry on a rack. Slides were then examined under the microscope with oil immersion (100x) objective. The presence or absence of parasites was observed and recorded.

\section{STOOL EXAMINATION}

\section{Saline and iodine smears:}

A drop of saline and one drop of iodine were placed on both ends of a clean grease free glass slide and pea size of stool emulsified on them. Each of the preparations were covered with cover slips and then examined with 10x and 40x objectives. Presence or absence of parasites was noted and recorded (King, 1982).

\section{Floatation Concentration Techniques:}

A piece of stool sample was emulsified in few drops of saline and the container filled with saturated sodium chloride solution (Brine) to the brim. A clean glass slide was placed across the mouth of the container. This was left for 15 minutes, after which the slide was carefully overturned and examined under the microscope with 10x objective (Cheesbrough, 1992).

\section{RESULTS AND DISCUSSIONS}

Results obtained in this study indicate that malaria and intestinal parasites are highly prevalent in the area. Of the 420 pupils examined $(86.9 \% ; 365 / 420)$ of them were infected (Table 1). A total of $273(65.0 \%)$ of them were infected with Plasmodium falciparium while $328(78.1 \%)$ had intestinal parasitic infection (Table II). 
Table 1: Relationship between parasitic infections and Haemoglobin $(\mathrm{Hb})$ values by age

\begin{tabular}{|c|c|c|c|c|c|}
\hline Age (Yrs) & $\begin{array}{l}\text { No Examined } \\
(\%)\end{array}$ & $\begin{array}{l}\text { No infected } \\
(\%)\end{array}$ & $\begin{array}{l}\text { Mean } \mathrm{Hb} \text { of } \\
\text { infected pupils (Hb } \\
\pm \text { S.D) }(\mathrm{g} / \mathrm{dl})\end{array}$ & $\begin{array}{l}\text { No uninfected } \\
\text { (5) }\end{array}$ & $\begin{array}{l}\text { Mean } \mathrm{Hb} \text { of uninfected } \\
\text { pupils }(\mathrm{Hb} \pm \mathrm{S} . \mathrm{D})(\mathrm{g} / \mathrm{dl})\end{array}$ \\
\hline $5-7$ & $87(20.71)$ & $74(85.06)$ & $10.3 \pm 1.0$ & $13(14.94)$ & $11.0 \pm 0.9$ \\
\hline $8-10$ & $130(30.95)$ & 121(93.08) & $10.6 \pm 0.8$ & $9(6.92)$ & $11.0 \pm 09$ \\
\hline $11-13$ & 172(40.95) & 158(92.94) & $10.7 \pm 0.3$ & $12(7.6)$ & $11.3 \pm 0.7$ \\
\hline $14-16$ & $31(7.38)$ & $29(38.00)$ & $11.2 \pm 0.6$ & $2(6.42)$ & $11.8 \pm 0.3$ \\
\hline Total & $420-$ & $365(89.90)$ & $10.7 \pm 0.3$ & $52(14.25)$ & $11.3 \pm 0.7$ \\
\hline
\end{tabular}

Table II: Distribution of Parasites and Haemoglobin $(\mathrm{Hb})$ levels by age of subjects

\begin{tabular}{ccccc}
\hline Age & No. Examined (\%) & \multicolumn{2}{c}{ No. Infected (\%) } & $\begin{array}{c}\text { Mean Hb value } \\
\text { (Hb } \pm \text { S.D) } \\
\text { g/dl) }\end{array}$ \\
\hline $5-7$ & & Blood & Stool & $10.4 \pm 1.0$ \\
$8-10$ & $87(20.71)$ & $(P$. falciporium) & Intestinal parasite \\
$11-13$ & $130(30.95)$ & $49(64.92)$ & $65(74.71)$ & $10.6 \pm 0.8$ \\
$14-16$ & $172(40.95)$ & $87(66.92)$ & $103(79.23)$ & $10.2 \pm 0.6$ \\
Total & $31(7.38)$ & $124(72.09)$ & $144(83.72)$ & $11.2 \pm 0.8$ \\
\hline
\end{tabular}

The high prevalence of these infections may be attributed to high prevalence of female anopheline mosquitoes and the breeding sites to sustain them. In a related study Mott et al. 1990 had identified factors such as poor personal and environmental hygiene, lack of pipe-borne water and overcrowding as the major cause of the high prevalence of the intestinal parasites. In this study those factors were not evaluated.

There was an increase in infection rate with age followed by a decline from age $14-16$, (Table III). A lumbricoides was the most common helminth parasites and involved $230(71.88 \%)$ children, followed by hookworm in 226 (68.9\%). Infections with intestinal protozoa were the least frequent; E. histolytica and E.coli $(32.94 \%)$ and G.lamblia $(7.32 \%)$. Other studies by Ejezie et al, (1993) in an adjoining community showed similar pattern. This may be a reflection of the fact that intestinal parasitic infections are endemic in these localities.

Table III: Occurrence of Intestinal Parasites by Age of Subject

\begin{tabular}{cccccccc}
\hline Age & $\begin{array}{c}\text { No } \\
\text { Examined } \\
(\%)\end{array}$ & $\begin{array}{c}\text { *No infected } \\
(\%)\end{array}$ & Ascaris (\%) & $\begin{array}{c}\text { Hookworm } \\
(\%)\end{array}$ & T. trichiura & G. laublia & $\begin{array}{c}\text { E. } \\
\text { histolytica/col } \\
\text { i }\end{array}$ \\
\hline $5-7$ & $87(20.71)$ & $65(74.71)$ & $39(60.00)$ & $44(67.69)$ & $20(30.70)$ & $7(10.77)$ & $10(15.38)$ \\
$8-10$ & $130(30.95)$ & $103(79.23)$ & $69(66.99)$ & $70(67.96)$ & $39(37.86)$ & $6(5.83)$ & $32(37.07)$ \\
$11-13$ & $172(40.95)$ & $144(83.72)$ & $113(78.47)$ & $102(70.83)$ & $50(34.72)$ & $9(6.25)$ & $56(38.89)$ \\
$14-16$ & $31(7.38)$ & $16(51.61)$ & $9(56.26)$ & $10(62.50)$ & $4(25.00)$ & - & $9(56.25)$ \\
Total & 420 & $328(78.88)$ & $230(71.88)$ & $226(68.90)$ & $113(34.45)$ & $24(7.32)$ & $107(32.94)$ \\
\hline
\end{tabular}

${ }^{*} \mathrm{~A}$ case of mixed infection is counted as single positive in the various infections.

Although males had higher prevalence rates of both malaria and intestinal parasites than females, there was however no statistical difference $X^{2}=0.6077<3.841 ; X^{2}$ $=0.4018<3.481(P>0.05)$. (Take IV). This indicates no genetic specific relationship, regarding transmission. The slightly higher prevalence among males may be due to higher exposure rate as males are known in this community to be involved in activities that predispose them to infection, like farming, playing football in open fields where are sometimes also used as defaecating grounds, in addition to staying late outdoors, a habit traditionally not permissible for girls. Secondly, the number of males involved in this study was more than the number of females as more boys were willing to submit themselves for the study than the girls.

Evaluation on the haemoglobin $(\mathrm{Hb})$ revealed significantly lower values difference $X^{2}=4.862>1.684$; $X^{2}=14.085>1.167(P<0.05)$ among those infected than in those not infected (Table V). This supports the finding of Ejezie et al (1993) that these parasitic infections may have been responsible for the cases of anemia seen in these age groups. Apart from parasitic involvement, the anemia seen among the $5-9$ years old may also be attributable to other factors such as malnutrition, folic acid and, vitamin B12 deficiencies, and sickle cell disease which this study did not evaluate. 
Table IV: Distribution of Intestinal Parasite and Plasmodium falciparium by sex

\begin{tabular}{cccc}
\hline Sex & No. Examined & No. infected & P-Values \\
\hline Intestinal parasite & & & \\
Female & $180(42.86)$ & $100(55.55)$ & $\mathrm{X}^{2}=0.6077<3.841$ \\
Males & $240(57.14)$ & $142(78.89)$ & $\mathrm{P}=>0.05$ \\
Total & $\mathbf{4 2 0}$ & $\mathbf{3 4 2}(\mathbf{8 1 . 4 3})$ & \\
P. falciparium & & & \\
Female & $180(42.86)$ & $120(66.67)$ & $\mathrm{X}=0.4018<3.841$ \\
Males & $240(57.14)$ & $171(71.25)$ & $\mathrm{P}=>0.05$ \\
Total & $\mathbf{4 2 0}$ & $\mathbf{2 9 1 ( 6 9 . 2 9}$ &
\end{tabular}

There was a direct relationship between $\mathrm{Hb}$ levels and the number of parasites; those harboring three or more types of parasites were found to be more anemic than those found with fewer parasites. Only three types of intestinal helminthes and two types of intestinal protozoal infection were encountered. The ecological and weather conditions of the area which favour this narrow range of parasites are not clear. Further studies may be necessary to evaluate the influence of these variables on parasite transmission patterns. Finally this research has shown the high prevalence of malaria and intestinal parasites among pupils in Akpet Central, Biase Local Government Area of Cross River State, because these infections presumably contributed largely to most of the anaemia cases reported in this area. It is suggested that periodic deworming of school children at least six monthly interval be embarked upon in this community. Health education to eliminate breeding sites for mosquitoes and promote the protective use of insecticide-treated bed nets; window and door nets should be emphasized.

\section{REFERENCES}

Bate, I., Mckew, S., Sarkingada, F., 2007. Anaemia: A useful indicator of Neglected disease burden and control Plos Med 4(8): e231.

Chessbrough, M., 1992. Medical Laboratory manual for Tropical Countries, vol. 1. $2^{\text {nd }}$ ed. Butterworth Heinemann Ltd. Oxford. 221 - 230, 243 - 259.

Ejezie, G. C., Emeribe, A. O. Igwe, M. A. 1993. Human Ecology and parasitic infections in Nigeria. Relationship between parasitic infections and anaemia. Journal of Medical Laboratory Sciences 3: $22-26$.

Evatt, B. L. Gibbs, W. N. Lewis, S. M. McArthur, J. R., 1992. Fundamental Diagnostic Haematology: Anaemia, United States Department of Human Services Atlanta 1-2: $63-64$.

Ezeamana, A. E., Friedman, J. F., Olveda, R. M. Acosta, L. P., Kurtis, J. D., 2005. Functional Significance of low intensity polyparsites helminth infection in anaemia. J. Infect. Dis 192: 2160 - 2170.
Friedman, J. F., Kanzaria, H. K., McGarvey, S. T. 2005. Human schistotomiasis and anaemia: The relationship and Potential Mechanisms. Trend parasitol 21: $386-392$.

King, M. 1982. Textbook of Medical Laboratory for Developing Country. Oxford University Press. Oxford $2-20$.

Mott, K. E., Desjeux, P., Moncayo, A., Ranque, D., Randitt, P. D., 1990. Parasitic disease and urban development Bull Wild HIth Org. 69(16): 698.

Murray, C. J. L., Lopez, A. D. 1996. The Global Burden of Disease. Harvard University Press.

Randath, D. D., Simeon, D. T., Wong, M. S. Grantham McGregor, S. M., 1995. Iron status of school children with varying intensities of Trichuris trichuria infection. Parasitology 110: 347 - 351 pt 3.

Stephenson, L. S., Holand, C. V., Cooper, E. S., 2000. The Public Health Significance of Trichuris trichuria. Parasitology 121 (suppl) 873 - 895.

Stoltzfus, R. J., Albonico, M. Chwaya, H. M., Salvioli, L., Tielsch, J., 1996. Homoquant determination of Hookworm - related blood loss and loss its role in iron deficiency in African children. Am. J. Trop. Med. Hyg. 55: 399 - 404.

United Nations 20007. The UN Millennium Development goals.

Weatheral, D. J., Ledingham, J. G. G., Warrel, D. A., 1985. Oxford Textbook of Medicine Vol. II, Oxford University press, Oxford Pg. $1-19$.

World Health Organization 1969. Parasitology of Malaria. Report of WHO Scientific group WHO. Tech. Rep. Ser. No. 433.

World Health Organization 1991. Basic Laboratory Methods in Medical Parasitoloty. Pg. $25-27$. 